\title{
Histórias de um lugar onde "preconceitos raciais nunca houve": os negros nas matas do Rio Grande do Sul (1889-1930)
}

Marcio Antônio Both da Silva*

\section{RESUMO}

O lugar, as açôes e a inserção social das populações negras no contexto da região de matas do Rio Grande do Sul durante o período da Primeira República são a temática central abordada neste artigo. Com base na atual produçáo historiográfica produzida sobre o assunto e por meio da análise de situaçóes vividas por homens e mulheres negras descritas em processos-crime movidos nas comarcas dos municípios de Cruz Alta, Palmeira das Missóes e Santo Ângelo, busco discutir e conhecer a realidade vivida por tais populaçóes em uma regiáo que na época foi objeto de um intenso processo de povoamento.

Palavras-chave: negros; pós-abolição; preconceitos; liberdade; fronteira agrária.

\section{ABSTRACT}

This paper addresses the place, the actions and the social insertion of Black people in the context of the forested area of Rio Grande do Sul, during the period of the First Republic. Based on the current historiographical production on the subject, and through the analysis of some situations experienced by Black men and women, which are described in criminal lawsuits filed in the Counties of Cruz Alta, Palmeira das Missões and Santo Ângelo, I seek to know and discuss the reality experienced by such populations in a region that lived, at the time, an intense settlement process.

Keywords: Black people; post-Abolition; prejudices; freedom; agrarian frontier.

Artigo recebido em 20 de março de 2013 e aceito em 14 de agosto de 2013.

DOI - http://dx.doi.org/10.1590/2237-101X015028011

* Doutor em história pela Universidade Federal Fluminense, professor da Universidade Estadual do Oeste do Paraná. Marechal Cândido Rondon, PR, Brasil. E-mail: marcioboth@gmail.com. 
Histórias DE UM LUGAR ONDE "PRECONCEITOS RACIAIS NUNCA HOUVE": os NEgRos Nas MATAS do Rio Grande do Sul (i 889-I930)

Marcio Antônio Both da Silva

\section{Introdução}

A produção de pesquisas sobre as populaçôes negras no pós-abolição, nas últimas décadas, conheceu um significativo desenvolvimento, sendo considerável o número de teses de doutorado, dissertaçóes de mestrado, artigos acadêmicos e livros produzidos sobre a questão. ${ }^{1}$ Embora isso não signifique que o assunto tenha sido encerrado e que não existam mais aspectos sobre a problemática para serem pesquisados, a elaboração de estudos sobre o tema encontra alguns obstáculos. Talvez, o principal deles seja aquele que se refere às fontes. De modo geral, é bastante difícil encontrar documentos que possibilitem um conhecimento particular sobre os negros no imediato pós-1888, especialmente porque, como demonstra a historiografia, as referências às populaçôes negras, tanto no Brasil quanto em outros territórios que conheceram o trabalho escravo, diminuíram expressivamente em comparação com o período escravocrata. ${ }^{2}$

Todavia, essa dificuldade vem sendo superada a partir da utilização de fontes diversas daquelas que tradicionalmente eram usadas até algum tempo atrás (geralmente documentos oficias produzidos pelo Estado ou narrativas de época). Além da utilização de outros tipos de fontes - relatos orais produzidos por descendentes de escravos, ${ }^{3}$ por exemplo — , alguns questionamentos vêm sendo feitos às fontes tradicionais, a partir da aplicação de novas teorias, produzidas nas últimas décadas, ou com base em interpretaçóes e reinterpretaçóes de abordagens clássicas.

Outra questáo importante sobre o assunto diz respeito às temáticas que preocupam os pesquisadores. Nesse caso, nos últimos anos também assistimos a um redirecionamento, uma vez que passamos da preponderância de análises que tinham como foco a inserção dos ex-escravos no mundo do trabalho e que tinham como mote principal a situação econômica dos egressos da escravidáo, para estudos que passaram a se preocupar com problemas relacionados à cultura, à cidadania, à identidade, à família negra, à resistência e à participação política. Isto não significou um abandono total dos estudos sobre as questóes econômicas e sobre os negros e o mundo do trabalho, mas a elaboraçáo de novas abordagens influenciadas por novos referenciais teóricos, como o marxismo de Edward Palmer Thompson. ${ }^{4}$

\footnotetext{
${ }^{1}$ Uma amostra, ainda que incompleta, dessa produção será relacionada ao longo do artigo.

2 SCOTT, Rebecca J. Emancipação escrava em Cuba: a transição para o trabalho livre (1860-1899). Rio de Janeiro: Paz e Terra; Campinas: Unicamp, 1991; COOPER, Frederick; HOLT, Thomas C.; SCOTT, Rebecca J. Além da escravidão: investigaçóes sobre raça, trabalho e cidadania em sociedades pós-emancipação. Rio de Janeiro: Civilização Brasileira, 2005; MATTOS, Hebe Maria. Das cores do silêncio: os significados da liberdade no sudeste escravista, Brasil século XIX. Rio de Janeiro: Nova Fronteira, 1998.

${ }^{3}$ RIOS, Ana Maria Lugão; MATTOS, Hebe Maria. Memórias do cativeiro: família, trabalho e cidadania no pós-abolição. Rio de Janeiro: Civilização Brasileira, 2005.

${ }^{4}$ Demonstrativo disso são os trabalhos produzidos por Sidney Chalhoub e Marcelo Badaró.
} 
Da mesma forma, a atual produção historiográfica também rompeu com a visão do negro em estado de anomia, a qual postulava que os ex-escravos, em função de carregarem a herança da escravidão, necessariamente deveriam ocupar um lugar subordinado e submisso na sociedade. Tal ponto de vista esteve muito presente no Brasil durante o período da abolição e também encontrou ecos em estudos realizados posteriormente por autores como Florestan Fernandes 5 e Celso Furtado. ${ }^{6}$ Os novos estudos produzidos demonstram que os grupos egressos da escravidáo não deixaram de lutar por seu reconhecimento e, em vez de agentes passivos da história, foram seus protagonistas diretos. Em outros termos, longe de serem simples vítimas, mesmo na condição de escravos, os negros não deixaram de lutar por seu reconhecimento e sua dignidade, e fizeram isso embasados em concepçôes próprias de vida, de liberdade e de cidadania.

Ainda em relação aos estudos produzidos, outro assunto importante é o do contexto espacial abordado pelas pesquisas. Nesse sentido, uma mirada nos temas das teses, dissertações, dos artigos e livros inicialmente mencionados demonstra que, em sua maioria, o foco das análises está direcionado para as principais cidades brasileiras, geralmente capitais estaduais como Rio de Janeiro, São Paulo, Salvador e Porto Alegre. Tal fato indica uma lacuna, isto é, a necessidade de avançar mais na perspectiva de entender o pós-abolição nos rincôes do Brasil, especialmente naqueles locais em que a presença negra não era tão grande, em comparação com os polos econômicos mais dinâmicos da sociedade brasileira.

Diante dessas observaçôes iniciais, o objetivo deste artigo é discutir assuntos relacionados à inserção social dos grupos de egressos da escravidão que viviam em uma região do interior do estado do Rio Grande do Sul, no período da Primeira República. Trata-se de um espaço que tradicionalmente é conhecido como região de matas, ${ }^{7}$ que se situa na parte norte do estado e que, na época, conformava a última área de fronteira agrária ali existente. Lugar para onde, a partir do final do século XIX, foi direcionado o movimento colonizador, sustentado em políticas de povoamento formuladas pelo recém-implantado Estado republicano, e que tinha como meta ocupar a regiáo com imigrantes europeus e seus descendentes. ${ }^{8}$

\footnotetext{
${ }^{5}$ FERNANDES, Florestan. A integração dos negros na sociedade de classes. São Paulo: Ática, 1978.

${ }^{6}$ FURTADO, Celso. Formação econômica do Brasil. São Paulo: Companhia Editora Nacional, 1979.

${ }^{7}$ No Rio Grande do Sul, as regióes de campo são tradicional e historicamente o lugar da criação de gado e da grande propriedade, enquanto as áreas florestais são o espaço da agricultura e da pequena propriedade. Evidentemente que este registro náo pode ser tomado por regra, pois é possível encontrar grandes propriedades na região florestal, assim como pequenas propriedades nas regióes de campo, embora a pequena propriedade, comparativamente às regióes de campo, prepondere nos espaços onde originalmente dominava a floresta.

${ }^{8}$ Aqui é importante registrar que o fato de a região ter sido alvo direto da política de colonização com imigrantes europeus no período não significa que ali as relaçóes preconceituosas encontrassem lugar especial para sua realização. Assim, deve-se ter a clareza de que o preconceito de cor estava e, em certo sentido, ainda está disseminado na sociedade brasileira como um todo. Uma discussão interessante e importante sobre esse problema pode ser encontrada em: NOGUEIRA, Oracy. Preconceito de marca: as relaçóes raciais em Itapetininga. São Paulo: Edusp, 1998.
} 
Naquilo que diz respeito às fontes, a análise será realizada a partir de indagaçôes feitas ao conteúdo encontrado em alguns processos-crime movidos nas comarcas dos municípios de Cruz Alta, de Palmeira das Missões e de Santo Ângelo. Também farei uso de dados presentes nas mensagens presidenciais encaminhadas à Assembleia Legislativa e nas memórias de João Neves da Fontoura, um literato da Academia Brasileira de Letras que foi importante líder político no Rio Grande do Sul, e que, em alguns momentos de seu livro de memórias sobre o período da Primeira República, deixou impressōes sobre a relação entre negros e brancos no estado. ${ }^{9}$ Dessa forma, o objetivo é produzir uma análise que avance na constituição de conhecimentos sobre os negros no pós-abolição e, especialmente, mostrar a importância dos escravos, ex-escravos e descendentes na parte norte do Rio Grande do Sul, lugar que invariavelmente é apresentado e se autoapresenta como um espaço formado e construído somente pelo trabalho de imigrantes e descendentes de imigrantes europeus.

Tratar dessa regiáo no contexto da virada do século XIX para o XX significa discutir sobre um espaço territorial que estava passando por um intenso movimento de adensamento demográfico e de ocupação. Esse processo foi permeado por conflitos, e sua motivação não se restringiu à disputa pela terra, mas decorria do fato de ser um encontro e uma convivência em um mesmo espaço de diferentes grupos sociais (indígenas, negros, imigrantes e nacionais). Somadas às questôes étnicas, também existiam as diferenças de classe, pois os confrontos entre latifundiários e camponeses pobres estiveram muito presentes no modo como se organizou e desenvolveu o povoamento. Cabe destacar ainda a atuaçáo de empresas particulares de colonização, bem como o papel exercido pelo Estado no gerenciamento desse processo.

Grosso modo e de forma resumida, a parte norte do Rio Grande do Sul, principalmente nas regiốes onde há preponderância do bioma Mata Atlântica e em que a presença de florestas é dominante, foi uma das últimas áreas do estado a ser objeto de atenção quanto ao problema da sua ocupação. Longe de ser um "deserto demográfico" como tradicionalmente se postulava, a região foi território indígena de tribos guarani e kaingang. Ao longo dos séculos XVIII e XIX, ela "foi alvo de uma frente colonizadora formada de luso-brasileiros que se estabeleceu nas áreas de campos nativos ali existentes, ocupando as pastagens dos antigos municípios de Lages, de Palmas de Cruz Alta e de Passo Fundo, na forma de grandes propriedades". ${ }^{10}$ É dessa frente que se origina o grupo dominante regional, o qual "estava vinculado a um setor produtivo bastante dinâmico que produzia e conduzia tropas de gado e muares do extremo Sul do Brasil para o Sudeste, forçando abertura de novos caminhos, conquistando o espaço dos povos indígenas." ${ }^{11}$

\footnotetext{
${ }^{9}$ FONTOURA, João Neves da. Memórias: Borges de Medeiros e seu tempo. Rio de Janeiro; Porto Alegre; São Paulo: Editora Globo, 1957.

${ }^{10}$ SILVA, Marcio Antônio Both da; ZARTH, Paulo Afonso. Religiosidade popular, autoridades e conflitos no Alto Uruguai. In: VALENTINI, José Delmir; ESPIG, Márcia Janete; MACHADO, Paulo Pinheiro. Nem fanáticos, nem jagunços: reflexóes sobre o Contestado (1912-2012). Pelotas: Editora da Universidade Federal de Pelotas, 2012. p. 135-136.

${ }^{11}$ Ibid.
} 
Juntamente com essa expansão e nas margens dos caminhos construídos para o transporte das tropas "surgiu um campesinato, alimentado demograficamente por tropeiros, aventureiros, soldados desertores, agregados, escravos fugitivos das fazendas de gado e de indígenas destribalizados". ${ }^{2}$ Economicamente esse campesinato se sustentava praticando uma agricultura de subsistência associada ao extrativismo de erva-mate, produto que era nativo da região e foi, durante muito tempo, importante item a gerar divisas não só no Rio Grande do Sul, como também no Paraná e em Santa Catarina.

Nos anos finais do século XIX, a regiâo ainda foi palco de "uma onda de imigração e colonização de camponeses não ibéricos oriundos de diversos países da Europa”. Processo que causou um "forte impacto social e ambiental no território, modificando profundamente as formas de uso da terra, estreitando radicalmente os espaços para as populaçóes tradicionais" ${ }^{13}$ Além disso, deve-se levar em conta que, no desenvolvimento desse processo, "aos antigos grupos dominantes de origem pastoril somar-se-iam empresários de terra, madeireiros e comerciantes. Os velhos caminhos de tropas disputariam com as ferrovias o transporte de mercadorias". ${ }^{14}$

Essa breve descrição é demonstrativa da complexa gama de relaçôes sociais que se constituíram com o povoamento da região. No que diz respeito às populaçốes que participaram desse processo, embora os dados não sejam precisos, algumas fontes trazem indícios a partir dos quais é possível desenhar um perfil populacional da região. Em geral, tais informaçóes estão mais presentes em algumas descriçôes que foram produzidas na época, sendo também possível utilizar os dados dos censos demográficos. Evaristo de Afonso Castro, por exemplo, em 1887, relatava que a população de escravos existentes na "região missioneira" — espaço que compreende outros municípios além dos que são analisados aqui — era de 15 a 20 mil pessoas. ${ }^{15}$ Segundo os dados do senso de 1872, o número de escravos que viviam em Cruz Alta, Palmeira das Missóes, Passo Fundo e Santo Ângelo era de 4.317 pessoas. $^{16}$

A presença indígena é mais difícil de ser definida, mas segundo relatório da Diretoria de Terras e Colonização, produzido em 1910, o número de índios vivendo nos doze aldeamentos entâo em funcionamento era de 2.940 pessoas. ${ }^{17}$ A presença de imigrantes e seus

\footnotetext{
${ }^{12}$ Ibid.

${ }^{13}$ Ibid.

${ }^{14}$ Ibid.

${ }^{15}$ Evaristo de Afonso Castro era promotor público no município de Cruz Alta. Cf. CASTRO, Evaristo de Afonso. Notícia descritiva da regiáo serrana na Província de Sáo Pedro do Rio Grande do Sul compreendendo os municípios de Cruz Alta, São Martinho, Palmeira, Passo Fundo, Santo Angelo, São Luiz, Boqueirão, São Borja, São Francisco de Assis, Sáo Vicente e Itaqui. Cruz Alta: Tipografia do Comercial, 1887.

${ }^{16}$ Para uma análise mais detida sobre esses números, bem como sobre a distribuição desses escravos em diferentes atividades, ver: SILVA, Marcio Antônio Both. Campesinato negro nas matas do Rio Grande do Sul. In: ZARTH, Paulo Afonso (Org.). História do campesinato na Fronteira Sul. Porto Alegre: Letra \& Vício; Chapecó: UFFS, 2012. p. 172-194.

${ }^{17}$ GONÇALVES, Carlos Torres. Relatório da Diretoria de Terras e Colonização. In: GODOY, Candido José de. Relatório da Secretaria de Estado dos Negócios das Obras Públicas apresentado ao Exmo. Sr. Dr. Carlos
} 
Histórias DE UM LUGAR ONDE "PRECONCEITOS RACIAIS NUNCA HOUVE": os NEgRos Nas MATAS do Rio Grande do Sul (i 889-I930)

Marcio Antônio Both da Silva

descendentes já é mais significativa e aumenta na medida em que o século XIX avança em direção ao XX. Um fato demonstrativo disso é que, segundo os dois censos demográficos de 1872 e 1920, a população que vivia nos territórios formados pelos municípios de Cruz Alta, Palmeira das Missóes, Passo Fundo e Santo Ângelo neste período aumentou de 34.822 habitantes para 284.777 , isto é, cresceu mais de oito vezes o seu número inicial. ${ }^{18} \mathrm{Com}$ respeito à população formada por ervateiros, posseiros pobres e agregados, Hemetério Veloso da Silveira destacava, ao tratar dos habitantes da região em 1909, que

uma grande multidão de homens pobres, procedente da fronteira sul e de outros pontos, atraídos pela notícia da extraordinária abundância e superioridade da erva-mate; para aí concorreu, procurando arranchar-se como agregados das grandes propriedades rurais, ou dentro dos matos baldios, ou mesmo comprando fraçóes de campos, para criaçóes em pequena escala. ${ }^{19}$

A presença de grupos e instituiçóes (Estado, Igreja, empresas particulares de colonização etc.) tão diversos, que guardavam formas particulares de compreender o mundo, de se relacionar com o trabalho, com a propriedade, com o espaço e de praticar a agricultura, deu à regiáo o caráter de uma área de fronteira agrária. Dessa maneira, as pessoas que viviam na parte norte do Rio Grande do Sul, na virada do século XIX para o XX, experienciavam uma "situação de fronteira", para empregar os termos de José de Souza Martins. ${ }^{20}$ Isto é, viviam em um lugar que era espaço de encontros entre os diferentes. Encontros que poderiam redundar em desencontros que, por seu turno, resultavam em conflitos.

Nessa perspectiva, para compreender profundamente a realidade da regiáo deve-se ter em conta também que as pessoas que nela habitavam, além de possuírem inserções sociais e econômicas diferenciadas, viviam em distintas temporalidades históricas, visto que o tempo dos agentes estatais não era o mesmo dos negros e dos indígenas, que era diferente da concepção de tempo e de trabalho dos imigrantes, e assim por diante. Desse modo, ainda nos

Barbosa Gonçalves, presidente do Estado do Rio Grande do Sul, pelo secretário de Estado Candido José de Godoy, em 10 de setembro de 1910. Porto Alegre: Livraria do Globo, 1910. p. 93-157 (citação, p. 155).

${ }^{18}$ FUNDAÇÁO DE ECONOMIA E ESTATÍSTICA. De provincia de São Pedro ao estado do Rio Grande do Sul, 1803-1950. Porto Alegre: FEE, 1981; JARDIM, Maria de Lourdes Teixeira; BANDEIRA, Marilene Dias. Um século de população no Rio Grande do Sul (1900-2000). Porto Alegre: FEE, 2001.

${ }^{19}$ Hemetério José Velloso da Silveira por muitos anos ocupou o posto de vereador e presidente da Câmara do município de Cruz Alta. SILVEIRA, Hemetério José Velloso da. As missóes orientais e seus antigos domínios. Porto Alegre: Companhia União de Seguros Gerais, 1979. p. 326.

20 "A fronteira é essencialmente o lugar da alteridade. É isso o que faz dela uma realidade singular. À primeira vista é o lugar do encontro dos que por diferentes razóes são diferentes entre si, como os índios de um lado e os civilizados de outro; como os grandes proprietários de terra, de um lado, e os camponeses pobres, de outro. Mas o conflito faz com que a fronteira seja essencialmente, a um só tempo, um lugar de descoberta do outro e de desencontro. Náo só o desencontro e o conflito decorrentes das diferentes concepçóes de vida e visóes de mundo de cada um desses grupos humanos. O desencontro na fronteira é o desencontro de temporalidades históricas, pois cada um desses grupos está situado diversamente no tempo da História." Ver: MARTINS, José de Souza. Fronteira. A degradação do Outro nos confins do humano. São Paulo: Hucitec, 1997. p. 150-151. 
termos de Martins, a regiáo como espaço de fronteira era um lugar de exploração, de revoltas, de resistências, de sonhos e de esperanças. Características que, como veremos, estavam presentes de forma muito visível no cotidiano dos habitantes da regiáo.

De maneira geral, foram essas as condiçóes de vida encontradas pelos negros na região. Foi lidando com elas, aos trancos e barrancos, mobilizando relaçóes, disponibilizando sua força de trabalho e atuando como ponta-de-lança no movimento das frentes de expansão da sociedade nacional, que os negros garantiram sua inserçâo social e lutaram por sua sobrevivência, mesmo enfrentando condições altamente adversas.

\section{"Um reino da igualdade": as visóes sobre o preconceito no Rio Grande do Sul e o vivido na região de matas no início do século XX}

A temática dos negros no pós-abolição ainda não recebeu atenção proporcional à sua importância, e são poucos os estudantes e pesquisadores que se arriscam a propor temas sobre o assunto. Além do problema das fontes mencionado, no caso do Rio Grande do Sul, pesa a existência de uma mítica ideia de que no estado, principalmente nas regióes de colonização, a presença negra é insignificante ou a de que uma suposta e inventada "cultura gaúcha" náo dá lugar para a existência de preconceitos entre os habitantes das terras rio-grandenses. Opiniâo que tinha seus adeptos e divulgadores na época da Primeira República. João Neves da Fontoura, em suas memórias sobre o período, deixa o seguinte registro ao tratar da democracia e da questáo do preconceito racial:

Inclusive pela nossa 'insularidade', a democracia abrangia também a sociedade, que era despretensiosa, mesmo entre os ricos. A índole da nossa formação, os hábitos da 'campanha', a necessidade de mútuo auxílio entre o fazendeiro e o peão, a fraternidade das urnas e das armas (cada fazendeiro era o chefe de seu clã político-partidário e, se preciso, o comandante militar de sua gente), tudo contribuía para fazer do Rio Grande um reino da igualdade. Preconceitos raciais nunca houve. ${ }^{21}$

Essa opiniáo, que teve e tem vários adeptos no Rio Grande do Sul, é facilmente contestada quando levamos em consideração e partimos do ponto de vista das populações negras e mestiças. Um exemplo disso ocorreu em Santo Ângelo, no dia 17 de fevereiro de 1923. Nesse dia, aconteceu uma festa à fantasia nas dependências do Clube Gaúcho, centro em que se reunia "a alta sociedade" do município. Participava da festa uma mulher negra de nome Perpedigna Rodrigues Camargo, que foi insultada por outras duas mulheres de nomes Clarinda Lourega e Eloyna Lourega Pinheiro. Segundo a queixa-crime feita por Perpedigna, no dia

${ }^{21}$ FONTOURA, João Neves da. Memórias, op. cit. p. 50. 
do baile, ao ir ao banheiro, encontrou-se com Clarinda e Eloyna. As duas comentavam sobre a sua fantasia, fato que levou Perpedigna a intervir na conversa, daí resultando o seguinte comentário de Eloyna: "Não é conversa contigo, negra à toa!". Na sequência, Eloyna disse a sua interlocutora que Perpedigna era: "Uma negra sem importância... que, em São Luiz [município situado próximo a Santo Ângelo], não era da Sociedade e é até um desaforo se achar metida na Sociedade desta vila... que era um resto dos negros". ${ }^{22}$

A situação vivida por Perpedigna demonstra que a participação no suposto "reino da igualdade" descrito por Joáo Neves da Fontoura dependia de determinados critérios, e a cor da pele era (e, em muitas situaçôes, ainda é) um deles. Em outras palavras, a categoria "ricos", da qual João Neves da Fontoura fazia parte, não era nada "despretensiosa", e a "democracia" tinha lá os seus limites.

Uma das principais expressóes do preconceito na época era a criminalização das populações negras. ${ }^{23}$ Esse fenômeno não esteve presente apenas no pós-abolição, mas é anterior ao 1888, e ganha significados especiais a partir desta data. Em agosto de 1888, por exemplo, Rodrigo de Azambuja Villanova, que ocupava o cargo de vice-presidente da província, dava a seguinte amostra:

se era precária nas condiçóes normais a segurança individual e de propriedade, depois da promulgação da Lei de 13 de maio do corrente ano que declarou livres todos os escravos existentes, e como consequência depôs todos os contratos e obrigaçóes que se basearam em Leis que mantinham o elemento servil, a vida e a propriedade do cidadáo ficaram quase sem amparo e defendidas antes pelos recursos pessoais de cada um do que pelo poder social, a cuja sombra embalde procuram os ameaçados acolher-se pedindo garantias. ${ }^{24}$

A opiniáo expressa por Villanova não era isolada, mas demonstra a existência de um fenômeno que a historiografia tem denominado de "medo branco", ${ }^{25}$ isto é, o pavor que as açôes levadas a cabo pelos negros causavam na elite brasileira. Sidney Chalhoub constata que, para o caso do Rio de Janeiro, "o medo branco da cidade negra parece ter aumentado

\footnotetext{
${ }^{22}$ ARQUIVO PÚBLICO DO ESTADO DO RIO GRANDE DO SUL (Apergs). Processo-crime n. 1.562. Cartório Civil Crime. Município de Santo Ângelo, 1923. Maço 56.

${ }^{23}$ SCHWARCZ, Lilia. Retrato em branco e negro: jornais, escravos e cidadãos em São Paulo no final do século XIX. São Paulo: Companhia das Letras, 1987; RIBEIRO, Carlos Antônio Costa. Cor e criminalidade: estudos e análises da justiça no Rio de Janeiro (1900-1930). Rio de Janeiro: UFRJ, 1995; CUNHA, Olívia Maria Gomes da; GOMES, Flávio dos Santos (Org.). Quase-cidadão: histórias e antropologias do pós-emancipação no Brasil. Rio de Janeiro: FGV, 2007.

${ }^{24}$ VILLANOVA, Rodrigo de Azambuja. Relatório com que o Exmo. Sr. Dr. Rodrigo de Azambuja Villanova passou a administração da provincia de São Pedro do Rio Grande do Sul a S. Exa o barão de Santa Tecla, $1^{\circ}$ Vice-Presidente, no dia 9 de agosto de 1888.

${ }^{25}$ AZEVEDO, Célia Marinho de. Onda negra, medo branco. O negro no imaginário das elites (século XIX). Rio de Janeiro: Paz e Terra, 1987. MACHADO, Maria Helena. O plano e o pânico: os movimentos sociais na década da abolição. Rio de Janeiro: UFRJ; São Paulo: Edusp, 1998.
} 
com o fim da escravidão e da monarquia". ${ }^{26}$ Esse medo, somado às leituras feitas sobre o passado escravocrata produzidas na época ${ }^{27}$ e à forma como se processou a aboliçáo, tornaram os negros os "suspeitos preferenciais", e representantes por excelência daquilo que historicamente se convencionou chamar de "classes perigosas". ${ }^{28}$ Percepção esta que não se restringia apenas às elites nacionais e às populaçóes urbanas, mas encontrou respaldo em outros setores sociais, inclusive entre as populaçôes de lavradores pobres.

Um fato demonstrativo ocorre em 1914, na Freguesia de São Miguel, terceiro distrito de Santo Ângelo, e é registrado em processo-crime movido para apurar os motivos da morte de Antônio Ferreira de Oliveira, ocorrido nas proximidades da residência de Ricardo Antunes Ribas (51 anos de idade, casado, empregado público). Segundo depoimento de Ricardo Ribas, havia quatro ou cinco dias, rondava próximo a sua casa um "indivíduo desconhecido de cor preta, trajando camisa vermelha, calças pretas e chapéu de palha". O negro, ainda de acordo com Ribas, fora visto pelos seus filhos, por uma "negrinha de um seu vizinho" e pela esposa do falecido Antônio de Oliveira, de nome Vitalina Maria de Melo, e toda vez em que era visto, o negro "corria para o interior do mato". ${ }^{29}$ Ricardo Ribas, ao ficar sabendo daquilo que estava acontecendo, "foi tomando sérias desconfianças", até que resolveu "convidar algumas pessoas para fazer busca e ver se descobriam o tal indivíduo". Para tanto, convidou seu sobrinho de nome Amado de Souza e seu vizinho Antônio Ferreira de Oliveira (o futuro falecido), os quais combinaram "convidar mais algumas pessoas e fazerem uma busca geral para a descoberta do misterioso negro" (grifos no original).

Na noite de 28 de novembro de 1914, Antônio Ferreira de Oliveira, sua mulher e filhos resolveram ir posar (pernoitar) na casa de Ricardo para, na manhã seguinte, realizarem a busca. Nessa mesma noite, estavam reunidos Ricardo, seus filhos, Amado de Souza (peão de Ricardo), Antônio Ferreira (que tocava gaita) e sua mulher, Vitalina. Em um dado momento, Ricardo diz ter ouvido "fortes trombadas na porta da varanda, entáo chamou que viessem ajudá-lo". Nisso chegou Antônio, segurando uma espada e uma pistola. Ricardo exigiu que ele cuidasse daquela porta e que reagisse caso alguém quisesse entrar, voltando à sala da casa para prevenir Amado e o peão. No entanto, quando chegou lá, ambos tinham saído. Ricardo voltou à porta onde tinha ficado Antônio e percebeu que este também havia saído. Em seguida aconteceu forte tiroteio, e Ricardo passou a gritar para que parassem de atirar.

\footnotetext{
${ }^{26}$ CHALHOUB, Sidney. Medo branco de almas negras: escravos, libertos e republicanos na cidade do Rio. Revista Brasileira de História. São Paulo, v. 8, n. 16, p. 83-105, p. 104, mar./ago. 1988.

${ }^{27}$ Leituras que se pautavam na noção de que, devido à experiência da escravidão, os negros não teriam condiçôes intelectuais e mentais para lidar com a liberdade. Além de apresentarem tendência ao ócio, por perceberem o trabalho como uma maldição, as populaçóes saídas da escravidão eram percebidas como despreparadas para responder aos estímulos econômicos e sem hábitos de vida familiar.

${ }^{28}$ CHALHOUB, Sidney. Cidade febril: cortiços e epidemias na corte imperial. São Paulo: Companhia das Letras, 1996. p. 21-24.

${ }^{29}$ Apergs. Processo-crime n. 1.370. Cartório Civil Crime. Município de Santo Ângelo, 1914. Maço 45.
} 
Quando os tiros pararam, Ricardo perguntou o que havia acontecido, ao que Amado Rodrigues respondeu: "Segurei o bandido" (grifos no original). Contudo, quando foram verificar, tiveram a surpresa de que "em vez de ser o suposto bandido, era o cadáver de Antônio Ferreira que se achava com suas armas nas mãos, (...), tendo recebido de Amado dois balaços sendo um no peito e outro no crânio, que morreu instantaneamente"30 (grifos no original). Os envolvidos no fato são interrogados, e todos confirmam a versão descrita aqui. Em consequência, Amado Rodrigues é levado a julgamento, mas o juiz não o pronuncia.

A situação descrita no processo-crime evidencia que a associação entre negritude e crime não estava presente apenas nos jornais e na literatura produzidos na época, mas era móvel de determinados comportamentos, pois a presença de uma pessoa de "cor preta" rondando a casa de Ricardo Ribas levou-o a, juntamente com seus vizinhos, tomar toda uma série de prevençôes, e, independentemente se o desconhecido fosse ou não um criminoso, Ribas tratou de organizar uma escolta para procurá-lo. Da mesma forma, deve-se levar em conta que a desventura vivida por Antônio Ferreira e Amado Rodrigues teve por base apenas a suposiçáo de que o misterioso negro fosse um bandido, e de que era ele o responsável pelo barulho na porta da casa onde o grupo estava reunido.

Os dois casos até agora citados dizem muito sobre o contexto local e evidenciam as facetas que adotou o processo de transiçáo de uma ordem social escravista para outra de trabalho livre. Essa mudança trouxe consigo os germens de conflitos que ganharam contornos singulares no pós-abolição. Da mesma forma, as situações presentes no segundo caso demonstram que o "medo branco de almas negras" não se restringiu às camadas mais bem situadas economicamente da sociedade brasileira, mas encontrou repercussão em diferentes contextos, sendo que a associação entre cor e criminalidade passou a ser acionada nos mais diferentes acontecimentos e com objetivos diversos.

Essas ocorrências têm muita relação com o problema da liberdade, ou melhor, os indícios encontrados nas fontes e a bibliografia que tem tratado da questão demonstram que as "visôes de liberdade", ${ }^{31}$ na passagem da ordem escravocrata para a de trabalho livre tinham lá seus desencontros. Ou seja, para parte significativa da populaçáo branca, ou que se considerava branca, a liberdade dos negros se restringia à condição de continuarem exercendo as mesmas funções que antes, na condição de escravos, exerciam. Contudo, para os negros, os significados da liberdade conquistada em 1888 eram mais amplos, exprimiam, entre outras coisas, usufruir da possibilidade de ir e vir sem necessariamente ter de prestar contas a ninguém, ${ }^{32}$ bem como a liberdade de lutar e defender os seus direitos. ${ }^{33}$

\footnotetext{
${ }^{30}$ Ibid.

${ }^{31}$ CHALHOUB, Sidney. Visóes da Liberdade: uma história das últimas décadas da escravidão na corte. São Paulo: Companhia das Letras, 1999.

${ }^{32}$ Para aprofundar esta questão, ver: FONER, Eric. O significado da Liberdade. Revista Brasileira de História. São Paulo, v. 8, n. 16, p. 9-36, mar./ago. 1988.

${ }^{33} \mathrm{Em}$ Terra de preto, Elione Guimarães apresenta uma série de exemplos ocorridos no vale do Paraíba mineiro
} 
Em suma, as populaçóes negras não deixavam de realizar sua liberdade das mais distintas maneiras. Fato que encontrou formas bastante interessantes no contexto da regiáo de matas do Rio Grande do Sul. Em seu estudo sobre os trabalhadores fabris de Ijuí — primeira colônia fundada no Rio Grande do Sul após a Proclamação da República —, Regina Weber analisa o caso de um assassinato ocorrido em baile promovido por um grupo de trabalhadores do principal frigorífico da cidade, evento no qual era proibida a presença de negros. O móvel do crime foi porque, mesmo diante da proibição, um "indivíduo de cor", usando de sua "liberdade" e do fato de que era sócio da entidade que promovia o evento, resolveu entrar no recinto e, além disso, convidar uma das moças presentes para dançar. Essa atitude não agradou nada aos promotores do baile, especialmente ao namorado da moça. Este acabou brigando com o negro, resultando disso a sua morte. ${ }^{34} \mathrm{O}$ sucedido é demonstrativo das leituras diferenciadas sobre a liberdade, pois para o negro que resolveu entrar no baile, sua condição de livre o autorizava a participar de eventos em qualquer lugar. Contudo, para os organizadores da função festiva, a liberdade dos "de cor" se restringia à porta do local onde ela acontecia.

Casos como esse não eram incomuns na região. Mas alternativas existiam. Em 1913, no povoado de Tupanciretâ, à época distrito do município de Cruz Alta, também ocorreu um baile em que houve um assassinato. Entretanto, nesse caso, o promotor do bailado era um "preto" de nome Caetano Francisco da Silva. Na denúncia, consta que Caetano fizera o encontro com a intenção de "se divertir com seus comparsas, ou no intento de auferir lucros com os afamados bailes de entrada paga, em que o anfitrião vende as libaçôes”. O autor da denúncia-crime ainda registra que figuravam como frequentadores da reunião dançante "indivíduos de baixa condiçấo social" ${ }^{35} \mathrm{O}$ motivo do assassinato ocorrido não envolveu questóes de cor e preconceito, mas o encontro promovido por Caetano evidencia que, se os negros não poderiam ou não eram bem-vindos nos divertimentos promovidos pelos brancos, nada os impedia de eles mesmos executarem os seus.

Não obstante, quando isso acontecia, a recepção não era das melhores, já que, pelo menos, o conteúdo do processo indica que a reunião de tais pessoas gerava preocupação. Outro dado importante é o de que a promoção dessas "afamadas" reunióes dançantes era uma opção utilizada para adquirir algum pecúlio por parte de seus promotores. Além de ser um

\footnotetext{
a partir dos quais demonstra a luta de ex-escravos e seus descendentes para terem seus direitos de acesso à terra legalmente reconhecidos. Em muitos dos casos analisados por Guimarães, as terras eram legadas por antigos proprietários de escravos em testamento e em reconhecimento a serviços prestados. Contudo, devido a certos conchavos e às brechas na legislação, muitos herdeiros negros, alguns dos quais haviam recebido benefícios quando ainda eram escravos, não tiveram seus direitos de acesso a determinados territórios reconhecidos. Ver: GUIMARÁES, Elione. Terra de preto. Usos e ocupação da terra por escravos e libertos (Vale do Paraíba mineiro, 1850-1920). Niterói: Eduff, 2009.

${ }^{34}$ WEBER, Regina. Os operários e a colmeia. Trabalho e etnicidade no Sul do Brasil. Ijuí: Unijui, 2002. p. 192-206.

${ }^{35}$ Apergs. Processo-crime n. 1.913. Cartório Civil Crime. Município de Cruz Alta, 1913. Maço 125.
} 
ponto de encontro entre os tais "indivíduos de baixa condição social”, provavelmente eram uma alternativa interessante para seus promotores complementarem suas rendas e garantir condições mais dignas de vida. ${ }^{36}$

Outro aspecto demonstrativo da forma como os negros viviam na região e de como manejavam sua condição social é o da sua relação com as autoridades constituídas, a qual geralmente era perpassada por desentendimentos. Em Palmeira das Missóes, no ano de 1902, ocorreu um fato demonstrativo dessa circunstância. Consta no processo-crime que, no dia 9 de abril, o negro José Constantino dos Santos e seu companheiro Paulino Moreira, peóes de Leonel Maria da Rocha, estavam em uma casa de negócio, tendo deixado dois cavalos redomóes que vinham amansando próximos à venda, e desatados. Acontece que, perto do local onde estavam os cavalos, passou um rapaz de nome Conceição Antunes, que vinha puxando um cargueiro, e esse fato fez com que os cavalos assustados começassem a fugir. Constantino não gostou nada da situação e passou a agredir o rapaz do cargueiro. Contudo, nas proximidades estava um praça de polícia, o qual deu ordem de prisão ao agressor. Conforme o processo, Constantino afirmou "que não se entregava, desconhecendo aqui autoridades e que não só brigava com um como com vinte" ${ }^{37}$ Disso resultou forte contenda entre o policial e Constantino, que recebeu dois tiros, dos quais resultou a sua morte.

A frase de Constantino ganha sentido ao se levar em conta que o seu patrão - o referido Leonel Maria da Rocha - era uma das principais lideranças da oposição política aos governos do Partido Republicano Rio-Grandense (PRR) na região. Ao PRR eram vinculados os homens que governaram o Rio Grande do Sul durante os primeiros quarenta anos da República. Além disso, como liderança política, Leonel aglutinava em torno de si parte dos grupos subalternos que viviam no município de Palmeiras das Missóes e na regiáo como um todo. ${ }^{38}$ Desse modo, o negro Constantino expressou a opiniáo do grupo ao qual se ligava, de pessoas que se identificavam com uma determinada posição política. Em outros termos, a participação dos negros no mundo da política se dava por outras formas, diversas às oficiais. Dificilmente seriam candidatos ou pleiteariam cargos públicos, mas ao seu modo exigiam e lutavam pela defesa de seus interesses, e o faziam a partir da maneira como se inseriam na sociedade.

Nesse caso, a herança da escravidão e as interpretaçóes raciais têm muito a nos dizer, principalmente se tivermos em mente que o papel das opinióes sobre os negros era garantir a reprodução social, isto é, manter o mundo funcionando da mesma forma como funcionava

\footnotetext{
${ }^{36}$ Sobre as estratégias de sobrevivência que dizem muito sobre o modo de vida e da sociabilidade característica das populações camponesas brasileiras, ver: CANDIDO, Antônio. Parceiros do Rio Bonito: estudo sobre o caipira paulista e a transformação dos seus meios de vida. São Paulo: Duas Cidades; Ed. 34, 2001.

${ }^{37}$ Apergs. Processo-crime n. 52. Cartório Civil Crime. Município de Palmeira das Missóes, 1902. Maço 5.

${ }^{38}$ Para conhecer mais sobre a liderança política exercida por Leonel Maria da Rocha no contexto do município de Palmeira das Missóes e da região, ver: ARDENGHI, Lurdes Grolli. Caboclos, ervateiros e coronéis: luta e resistência no norte do Rio Grande do Sul. Passo Fundo: UPF, 2003.
} 
antes de 1888. Assim, tratar os negros como criminosos em potencial porque no passado haviam sido escravos, ou como social, mental e racialmente inferiores significava abrir a possibilidade de deslegitimar quaisquer açóes voltadas e executadas no sentido de efetivamente realizar a liberdade conquistada no 13 de maio, coisa que está muito presente na fala de Eloyna, ao se dirigir a Perpedigna e tratá-la como "um resto dos negros" que não "pertencia à Sociedade". De maneira um tanto diversa, mas trilhando o mesmo caminho, ao escrever que o Rio Grande do Sul era um "reino da igualdade", onde "preconceitos nunca existiram", João Neves da Fontoura jogava para os porões da história as falas e os comportamentos como os de Eloyna. Assim, silenciava os conflitos para, dessa maneira, justificar a dominação.

\section{O preço da cor: os negros no imediato pós-abolição}

Para finalizar, apresento um último fato ocorrido em Santo Ângelo e que ajuda a compreender a vida e as dificuldades enfrentadas pelas populaçóes negras no imediato pós-abolição. Segundo consta nos autos do processo, o crime ocorreu no 3o distrito do município — lugar conhecido como "Rincão dos Antunes" _ - na madrugada do dia 6 para 7 de dezembro de 1904, e foi perpetrado por Policarpo Cardoso de Oliveira, Pedro Cardoso de Oliveira (irmão de Policarpo) e João Antônio Felizardo. As vítimas eram Antônia de Oliveira Fucks e sua filha Alcinda de Oliveira, que tinha três anos de idade. As duas foram degoladas, e Antônia, depois de morta, ainda foi estuprada por Policarpo.

Antes de discutir a questão da cor e do preconceito presentes no desenrolar do acontecimento e do próprio processo-crime, convém apresentar um pouco mais detidamente, a partir daquilo que a fonte possibilita, os envolvidos na situação. $\mathrm{O}$ conjunto das pessoas arroladas ao longo do processo é composto em sua maioria por indivíduos que tinham como "meio de vida e profissão" a agricultura, e se identificavam como lavradores ou jornaleiros que prestavam serviços relacionados à agricultura ou ao manejo com o gado. Policarpo Cardoso de Oliveira, cujo protagonismo no crime está presente ao longo de todo o processo, afirmou, em seus interrogatórios, ter 24 anos de idade, ser solteiro, natural do Rio Grande do Sul, residente e domiciliado no terceiro distrito de Santo Ângelo e ter como "meio de vida e profissão" ser capataz do tenente-coronel Pacífico Correa Dornelles. Pedro Cardoso de Oliveira, irmão de Policarpo, disse ter entre dezessete e dezoito anos de idade, ser solteiro, natural do Rio Grande do Sul, residente no terceiro distrito e ser lavrador. João Antônio Felizardo afirmou ter 32 anos de idade, ser casado, natural do Rio Grande do Sul, residente no terceiro distrito "desde seu nascimento" e que "trabalha em todo serviço como pião (sic)". Antônia de Oliveira Fucks apenas é identificada como uma mulher que era "casada, porém separada de há muito tempo", e que vivia com sua filha, "em uma casinha situada no lugar denominado Rincão dos Antunes”. 
Conhecidos os qualificativos dos diretamente comprometidos, cabe agora apresentar as circunstâncias em que se deu o crime e as situaçóes relacionadas a ele. Um primeiro ponto que destaco é o de que todos os envolvidos eram conhecidos de há muito tempo e mantinham certas relaçóes, pois eram todos vizinhos e se conheciam mutuamente. Inclusive o sobrenome Oliveira indica o parentesco entre as vítimas e dois dos réus, relação que é confirmada no testemunho de um dos depoentes, o pai de Alcinda (o já citado Pacífico Corrêa Dornelles), que além de patrão de Policarpo, era seu tio em segundo grau.

As primeiras suspeitas da autoria do crime caíram sobre Luiza Cardoso, irmã de Policarpo e Pedro, suposição que tinha por fundamento o fato de que era voz corrente que Antônia e Luiza viviam uma relação de inimizade. A animosidade reinante entre as duas tinha por justificativa os ciúmes que uma entretinha pela outra em função de terem se envolvido em certa disputa amorosa. Da mesma maneira, era voz corrente no distrito que Luiza havia prometido matar Antônia e Alcinda. Contudo, ainda na fase de inquérito, Miguel de Oliveira Fucks, irmão e responsável por avisar o delegado sobre a morte de Antônia, ao ser questionado sobre suas suspeitas de quem poderia ter cometido o crime, afirmou que não tinha ideia, contando que, dias antes, sua irmá havia lhe dito que Policarpo Cardoso de Oliveira tinha ido até sua casa e feito propostas, oferecido dinheiro, inclusive, para passar a noite com ela, convite que foi recusado por Antônia. Munido dessas informaçóes e de alguns indícios encontrados no local do assassinato, o delegado passou a inquirir os possíveis suspeitos do crime.

$\mathrm{Na}$ primeira fase do inquérito, o delegado tomou o depoimento de dezesseis pessoas, dentre elas alguns membros da família Cardoso de Oliveira, vizinhos, parentes e amigos de Antônia Fucks. Os indícios coletados ao longo desses depoimentos levaram o delegado a chegar a Policarpo, Pedro e João Felizardo, e este último, quando inquirido, resolveu quebrar o pacto estabelecido entre os três e confessar sua participação na execução do crime. Em seu depoimento, João contou que, na passagem dos dias 6 para 7 de dezembro de 1904, retornava para sua residência ainda de madrugada quando, no caminho, encontrou com Policarpo e Pedro, os quais estavam próximos à casa de Antônia Fucks. Ao avistar os dois irmãos, João perguntou o que estavam fazendo e eles responderam que andavam caçando tatu. Na sequência, Policarpo ofereceu um trago de cachaça a João, que aceitou a oferta. Após tomar o trago, os irmãos Cardoso convidaram João a matar Antônia Fucks, e este disse ter recusado o convite. Mas Policarpo e Pedro insistiram e também ofereceram dinheiro e um cavalo para João, que, diante da oferta, assentiu. A partir disso, os três se dirigiram à casa de Antônia, que, em princípio, hesitou em atender às batidas na porta, mas Policarpo disse ser Joáo Germano. Diante dessa identificação, ela abriu a porta, sendo, em seguida, ameaçada à espada por Policarpo que

entrou porta adentro perseguindo-a e ao entrar gritou para ele respondente e Pedro que chegassem, eles chegando já encontraram a mulher caída na cama e Policarpo apertando-a 
disse a ele respondente que ajudasse a segurar, então ele respondente chegou e apertou-a nas pernas e Policarpo degolou-a. A filhinha pequena que dormia na mesma cama com sua mãe acordou-se com a luta que tiveram ao assassinarem sua mãe e começou a chorar muito, então Pedro agarrou-a e disse-lhe: agora tu pestinha vai passar pela mesma forma e, passando por cima da mãe que estava morta, foi e degolou-a. ${ }^{39}$

João ainda conta que, após matar Antônia, o algoz abusou sexualmente dela. Esse comportamento não era incomum em Policarpo, pois seu cunhado, José Giordani, em depoimento, contou que, quando o acusado trabalhou como capataz na fazenda de Pacífico Corrêa Dornelles, havia seduzido e engravidado uma moça, a qual, devido à gravidez, suicidou-se. No dia do velório, Policarpo, "um tanto embriagado", a "todo transe tentou violar o cadáver para saciar desejos libidinosos, o que foi impedido pelas pessoas que estavam presentes".

Após a confissão de João Felizardo e de ter revelado a atuação de Policarpo e Pedro, os irmãos foram inquiridos pelo delegado e apresentaram suas versóes sobre o fato. Ao ser interrogado, Policarpo disse que, diante da circunstância de que um de seus companheiros, que com ele havia jurado "nunca revelar o crime nem mesmo sujeitando-se à morte", tinha quebrado a promessa, resolveu declarar a verdade. Nesse primeiro depoimento, prestado ainda na fase de inquirição, Policarpo confessou o crime, e disse que havia dois meses, mais ou menos, antes de cometê-lo, tinha ido à casa de Antônia e oferecera a ela a quantia de 4 mil-réis para pernoitar com ele, oferta que foi recusada. Diante da recusa, Policarpo ofereceu à Antônia uma nota de 50 mil-réis para que ela trocasse e pegasse quanto quisesse, mas mesmo assim ela não aceitou a proposta e ele ficou "um tanto indignado e disse-lhe: tu hás de arrepender-te mais do que eu de não querer dormir comigo em tua casa hás de pagar".

Contudo, um tempo depois, quando Policarpo foi interrogado, na fase de julgamento, negou sua participação no crime, afirmando que, no dia em que Antônia foi assassinada, estava doente e de cama, na casa de seu irmão José Cardoso de Oliveira. Além disso, construiu uma nova versão sobre o desentendimento que teve com ela, no momento anterior ao crime. Ao ser perguntado se ele esteve na casa de Antônia e se tinha oferecido dinheiro para com ela pernoitar, Policarpo responde que

um mês antes esteve em casa da referida Antônia e que ele interrogado querendo retirar-se porque vinha chuva que, nessa ocasião, Antônia ofereceu-lhe a casa para pousar e ele interrogado não aceitando, Antônia respondeu que ele não pousava lá porque não tinha um mil-réis para dar para uma mulher branca e ia dar para uma Negra ( $i c$ ) duzentos réis e que ele interrogado um pouco incomodado com aquelas palavras tirou do bolso a quantia de cinquenta e quatro mil-réis dizendo que tinha dinheiro e que não era só duzentos réis ${ }^{40}$ (grifos meus).

\footnotetext{
${ }^{39}$ Apergs. Processo-crime n. 2.904. Cartório Civil Crime. Município de Santo Ângelo, 1904. Maço, 78. ${ }^{40}$ Ibid.
} 
Não é possível saber quais das duas versôes apresentadas por Policarpo é mais fiel à discussão travada entre ele e Antônia, embora a primeira esteja mais próxima daquela apresentada pelas testemunhas que tinham ficado sabendo do atrito entre os dois por meio da própria Antônia, antes de ela ser assassinada. Não obstante, o que chama atenção nesse segundo depoimento de Policarpo, além de ele ter negado a autoria do crime, é o ato de ter apresentado como possível justificativa de sua indignação a versão de que Antônia tinha dito que ele, devido a sua condição financeira, teria de procurar uma mulher negra.

O problema não está em descobrir qual a versão mais fiel ao acontecimento e sim perceber e compreender o peso da questáo da cor no modo como se constituíam as relaçóes sociais, visto que, ao apresentar o argumento em uma situação pública, diante do tribunal, Policarpo, mesmo que estivesse inventando o conteúdo da discussão, estava lidando dentro dos parâmetros do possível, socialmente falando. A cor definia lugares e status sociais naquele contexto, circunstância que fica visível na intenção de Policarpo em justificar sua indignação com Antônia por ela supostamente ter dito que ele não tinha condiçóes de pagar a uma mulher branca por seus serviços sexuais. Argumento que se materializa e exprime todo um sistema de diferenciaçóes sociais, quando Policarpo expressa que, naquele contexto, os "serviços" sexuais de uma mulher negra eram significativamente menos caros do que os de uma mulher branca.

Diante dessas informaçóes, cabe ainda acompanhar um pouco mais o desenrolar do processo-crime, pois há outros momentos em que a cor dos comprometidos no caso vai encontrar espaço de realização. Uma análise profunda do processo revela o quanto, na época, a cor dos envolvidos em determinadas questóes poderia se tornar um argumento jurídico altamente incriminador. Situação que está muito presente no modo como a atuação de João Felizardo, um negro, é retratada e tratada ao longo do processo, desde a inquiriçáo até o julgamento final, chegando inclusive a ter presença no pedido de liberdade condicional solicitada pelos irmãos Cardoso, em 1923, isto é, vinte anos depois de ter ocorrido o crime e os três terem sido condenados a trinta anos de prisão.

Como já mencionei, João Felizardo foi o primeiro a confessar o crime e a contar os detalhes sobre como ele aconteceu; diante dessa confissão, os irmãos Cardoso também assumiram sua participação, coisa que negaram quando do julgamento, especialmente a partir do momento em que passaram a ser assistidos por um advogado. Desse momento em diante, a cor de João foi constantemente invocada na perspectiva de ser considerado o único culpado. João, por sua vez, não conseguiu contratar um advogado para defendê-lo, e, assim, foi assistido por pessoa nomeada pelo juiz durante o julgamento, mas a presença desse defensor é quase nula ao longo do processo.

É perceptível nos depoimentos das testemunhas e das respostas dadas pelos irmãos Cardoso que, após a nomeação do advogado de defesa, a estratégia montada era a de responsabilizar unicamente o "crioulo" João Felizardo pelo crime, mas o plano acabou não funcionando. 
Diante da falha dessa estratégia inicial, o advogado dos irmáos Cardoso resolveu apelar da decisão, e, nesse momento, passou a representar a João Felizardo também. Todavia, tanto em segunda quanto em terceira instância, o pedido de revisão da pena não foi aceito, e Pedro, Policarpo e João foram encaminhados para cumprir sua condenaçáo na cadeia de Porto Alegre.

A partir desses dados, visualiza-se que a inserção de João no conjunto de relaçóes que constituíam a realidade social em que participava era bastante subordinada, mais até do que a de seus companheiros de crime, que, como ele, se declararam homens pobres que realizavam atividades vinculadas à lavoura ou ao manejo com o gado. Tais diferenças vêm à tona na circunstância de que Policarpo e Pedro conseguiram, via seus contatos, ser atendidos por um advogado. Além disso, apresentaram como testemunhas de defesa pessoas que eram consideradas importantes na esfera local e que mobilizavam certo capital simbólico. Em outras palavras, eram pessoas cujo peso das palavras alcançava maior legitimidade diante do tribunal e seus depoimentos davam força à defesa apresentada pelos irmáos Cardoso orientados por seu advogado. ${ }^{41}$ Isso fica evidente na circunstância de que o principal argumento da defesa escrita, juntada aos autos, propóe que, ao envolver Policarpo e Pedro no crime, João, orientado por algumas pessoas de Santo Ângelo, buscava atingir diretamente a "honra e respeitabilidade" do tenente-coronel Pacífico Corrêa Dornelles, patrão e parente em segundo grau de Policarpo e Pedro.

Por sua vez, a estratégia de culpar somente a Joáo pelo crime e os modos utilizados para realizá-la, em última análise, acabavam por legitimar a posição social que os irmãos Cardoso ocupavam, bem como davam uma realidade toda concreta ao preconceito racial. Entretanto, esse não é um processo simples, pois é preciso se ter em mente que a combinação e realização desses fatores só foram possíveis porque os discursos e posiçôes adotados durante o julgamento se adequavam e eram expressáo fiel da realidade social em que o fato julgado e o próprio julgamento aconteceu.

Da mesma forma, em 1923, quando os irmãos Cardoso solicitam sua liberdade condicional, juntaram aos autos cartas e documentos que atestavam sua boa conduta antes de perpetrarem o crime, produzidos por pessoas que se apresentaram e foram apresentadas como importantes na esfera local, um dos quais disse ter sido chefe de polícia em Santo Ângelo. Em outros termos, os irmãos Cardoso conseguiram mobilizar um capital social impossível de ser manejado pelo "crioulo" João Antônio Felizardo, e, muito embora tal manejo não tenha sido eficiente no sentido de isentá-los da punição, garantiu-lhes acesso a "benefícios", aos quais João Felizardo, devido a sua posição e inserção social, não teve acesso. Por sua vez, e é importante insistir de novo, ao utilizarem desses recursos, inconscientemente, os irmãos

\footnotetext{
${ }^{41}$ Nos termos do Pierre Bourdieu: "o poder simbólico é um poder de fazer as coisas com palavras. É somente na medida em que é verdadeira, isto é, adequada às coisas, que a descrição faz as coisas. Nesse sentido, o poder simbólico é um poder de consagraçáo ou de revelaçáo, um poder de consagrar ou de revelar coisas que já existem". Cf. BOURDIEU, Pierre. O campo econômico: a dimensão simbólica da dominação. Campinas: Papirus, 2000, p. 166-167.
} 
Cardoso estavam dando força e reproduzindo uma série de relaçóes e estruturas sociais que muito certamente eram as principais responsáveis por aquilo que estavam vivendo.

Outra característica presente no conteúdo dos depoimentos prestados pelas testemunhas de defesa é que elas carregam na tinta quando buscam responsabilizar unicamente João pelo crime. O tenente-coronel Pacífico Corrêa Dornelles (quarenta anos de idade, viúvo, criador), no início de seu depoimento, informou que, além de parente dos dois réus, era pai da menina Alcinda. Conta que, logo que ficou sabendo do crime, saiu em direção à casa das assassinadas, onde encontrou algumas autoridades locais, de quem exigiu rigor na descoberta do possível assassino, e que lá também estava o acusado Pedro Cardoso. Segundo Pacífico, Pedro "se achava em seu estado natural sem nenhuma alteraçáo pela qual revelava-se a autoria do trucidamento daqueles dois cadáveres que se achavam na sua presença". Policarpo, de acordo com Pacífico Dornelles, estava em casa de sua cunhada doente e "guardando cama". Diante disso, declara que supunha ser falsa a acusação de que Pedro e Policarpo haviam se envolvido no crime. Em relação a João Felizardo, Dornelles afirmou que era voz corrente que ele "é acostumado a tentar contra a honestidade de mulheres casadas", que ele era "gatuno e ladrão", e logo que soube do crime conjecturou que o autor era João. A primeira impressão causada pelo depoimento do tenente-coronel Pacífico causa estranheza, pois, como pai da menina assassinada, ele parece fazer um esforço bastante grande para livrar os irmãos Cardoso da acusação. A pergunta que fica é: a que se deve tal postura?

Responder a esse questionamento é bastante difícil, pois o processo não traz muitas informaçôes sobre como era a relação dos envolvidos antes do crime; contudo, fica claro que todos, com exceção de João, mantinham relaçóes muito íntimas, de parentesco inclusive. Assim, Pacífico Dornelles era pai de Alcinda, que vivia com sua mãe Antônia, apresentada como separada. Consequentemente, é possível crer que a relação entre Pacífico e Antônia não fosse das mais harmônicas. Dois dos assassinos eram da família que tinha lá seus atritos com a vítima, uma vez que a irmã (Luiza Cardoso) de Pedro e Policarpo era inimiga confessa de Antônia, não esquecendo que Policarpo era sobrinho em segundo grau e empregado de Pacífico (pai de Alcinda). Para complicar ainda mais esse conjunto de relaçôes, Policarpo e Antônia tinham discutido, supostamente porque ela não havia aceito a proposta de passar a noite com ele, e havia mandado procurar uma negra. Essa miríade de relaçóes leva à conclusão de que a morte de Antônia e Alcinda não foi um fato isolado ou somente obra dos instintos perversos daqueles que executaram o crime (como o processo-crime, especialmente no conteúdo do texto da sentença, dá a entender). Na verdade, o crime, o julgamento dos envolvidos, a forma que adotou o julgamento e o seu resultado são expressão de um tipo específico de sociabilidade que se constituiu no e a partir do processo de povoamento da regiáo. Processo que, por seu turno e por ser local, não estava desvinculado de uma realidade mais ampla e que dizia respeito ao Brasil do início do século XX.

Cabe ainda perguntar qual o lugar do "crioulo" João Antônio Felizardo em meio a tudo isso. Em suas próprias palavras, ele era um homem casado, que "trabalhava em todo serviço 
como pião (sic)", e que morava no terceiro distrito de Santo Ângelo, desde seu nascimento. Afirmou que aceitou participar do crime porque Policarpo e Pedro lhe ofereceram cachaça, dinheiro e cavalo para fugir, caso algum "caipora" resolvesse delatar o fato. Aos olhos da maior parte das testemunhas, João era um negro turbulento e de maus costumes. Muito provavelmente João tenha sido sincero ao alegar que o único motivo que tenha levado a participar do crime foram as ofertas realizadas pelos irmáos Cardoso, pois no processo não há qualquer indício que demonstre uma possível razão anterior que tenha levado João a querer matar Antônia e sua filha.

Dessa maneira, é provável que seu sim ao convite tenha como justificativa o fato de ter pouco a perder, e muito a ganhar, na sua participação, afinal, ele era um homem com fama de turbulento e, além disso, era negro, em um contexto em que a cor de pele era móvel de inserçóes e relaçóes sociais. Muito provavelmente, no momento do convite tenha sido convencido de que não seriam descobertos, e talvez tenha atuado em favor do convencimento a circunstância de que, na noite em que ocorreu o crime até o seu encontro com os irmãos Cardoso, estava em uma venda bebendo com alguns amigos e conhecidos, isto é, estava com seu juízo alterado. João também conta que, no momento em que Pedro degolou Alcinda e em que Policarpo abusou do corpo de Antônia, estarrecido diante da cena, fugiu para sua casa. Talvez o remorso e a repercussão do fato o tenham movido a, já no primeiro interrogatório, contar os detalhes do crime e quebrar a promessa que haviam feito.

Quanto aos irmãos Cardoso, como já escrevi, tinham lá seus atritos em relação à Antônia. Contudo, cabe indagar sobre os motivos que os levaram a convidar João a ajudar na realização do assassinato, pois os dois sozinhos tranquilamente poderiam dar conta do objetivo. Uma hipótese forte é a de que a presença de João naquele local e horário foi inusitada, logo, convidá-lo a participar seria uma forma de evitar que, no futuro, ele viesse a testemunhar que, na noite do crime, havia encontrado com os irmãos Cardoso nas proximidades da casa de Antônia. Contudo, ainda fica a curiosidade de saber se, caso João tivesse mantido sua recusa inicial, os irmãos Cardoso mudariam os seus planos.

Por fim, em 2 de maio de 1904, após julgamento e manifestação dos jurados sobre os quesitos, os três réus foram condenados a trinta anos de prisão, e houve apelação, sem sucesso, para segunda e terceira instâncias. Como já grifei, por volta do ano de 1923, os irmãos Cardoso pediram liberdade condicional, no que foram atendidos. Nesse pedido, continuaram afirmando que o único culpado pelo crime tinha sido o negro João Antônio Felizardo, o qual havia falecido na Casa de Correção de Porto Alegre, no dia 6 de setembro de 1918, vitimado por enterite tuberculosa. 


\section{Considerações finais}

O conjunto de situações e relações apresentadas a partir da leitura dos processos-crime discutidos ao longo do texto permite conhecer muito sobre a sociabilidade das populaçóes que viviam na região de matas do Rio Grande do Sul. Espaço geográfico que, na época, compunha uma das últimas áreas de fronteira agrária do estado. Lugar para onde, juntamente com a Proclamaçáo da República, foi direcionado o movimento colonizador que teve por principais agentes imigrantes provindos da Europa e descendentes de imigrantes que vinham das áreas de colonização antigas do Rio Grande do Sul — São Leopoldo e Caxias do Sul, por exemplo. Todavia, esse movimento não foi levado a cabo apenas por imigrantes e seus descendentes, pois é preciso dar a devida importância para a atuação e a presença de outros grupos sociais, cuja importância é igual ou maior do que a dos imigrantes. Neste texto, busquei analisar, a partir dos dados presentes em alguns processos-crime, a presença, a inserção social e a importância dos grupos egressos da escravidão no contexto do povoamento.

As análises aqui produzidas evidenciam que a realidade vivida pelos negros na região não era muito diferenciada daquela vivida pelas populaçóes negras que residiam nos grandes centros urbanos e em outros territórios do Brasil. Isto é, o preconceito racial estava disseminado na sociedade brasileira como um todo e perpassava as diferentes realidades sociais e econômicas. Perceber e analisar isso em termos da região de matas do Rio Grande do Sul, por um lado, significa trazer à tona um assunto ainda pouco discutido. Por outro, pensar tal problema tomando como ponto de partida fontes que possibilitam dar voz às populaçóes que viveram esse processo significa conhecer, mesmo que a partir de uma realidade local, uma face ainda pouco explorada da história do Brasil.

Assim, se no último processo-crime analisado a condição econômica de Policarpo, Pedro e João era mais ou menos semelhante, uma vez que eles se apresentaram como homens pobres que tinham como meios de vida e profissão serem lavradores (caso de Pedro e da maior parte das testemunhas chamadas a depor no processo) e peões (caso de Policarpo e João), a cor de João foi constantemente utilizada com o objetivo de culpá-lo pelo assassinato de Antônia e sua filha Alcinda. Diferentemente de João, Pedro e Policarpo conseguiram mobilizar um conjunto de relaçóes que foram estrategicamente utilizadas ao longo do julgamento e também após a condenação, lembrando que João morreu preso, e os irmãos Cardoso conseguiram sua liberdade condicional.

Os outros processos-crime analisados também indicam o quão difícil era a vida das populaçóes negras, e, sobretudo, demonstram que mesmo perante tais dificuldades elas lutaram e encontraram espaços para realizar sua liberdade, fato que se materializou quando Perpedigna prestou queixa e um processo-crime foi instaurado para apurar as ofensas a ela feitas, no baile do Clube Gaúcho de Santo Ângelo. De maneira semelhante, temos exemplo disso quando o negro José Constantino, diante da ordem de prisão emanada pelo subdelega- 
do de Palmeira das Missóes, disse que ali não reconhecia autoridade alguma. Acontecimento não muito diverso ocorreu quando, diante da proibição expressa da entrada de negros no baile organizado por alguns funcionários do Frigorífico Serrano, em Ijuí, um negro resolveu participar do evento, e ainda convidou uma das moças ali presentes para dançar.

Os processos-crime também mostram quão ousadas eram essas pessoas, pois suas atitudes invariavelmente eram alvo da violência, tanto física quanto moral. O que se evidencia na situação vivida por João Felizardo, que morreu na prisão, pelo negro que entrou no baile dos brancos em Ijuí, por José Constantino, que recebeu dois tiros ao resistir à voz de prisão, pelo misterioso negro que não foi alvo direto da violência, mas que esteve sob a mira atenta de Ricardo Ribas e seus vizinhos, e por Perpedigna, que, no banheiro do Clube Gaúcho, foi alvo de uma série de ofensas. Como é perceptível, a maioria desses casos ocorreu em momentos em que os negros participavam de situaçôes ou estavam em lugares que, "por serem negros", não deveriam estar. Todavia, mesmo diante dos perigos que sua presença em tais locais e situações representava a si próprios — muito provavelmente eram sabedores disso —, eles não se isentavam de lá estar e, assim, de romper o silêncio. Enfim, estavam longe de serem os vadios e "retardados" mentais que se buscava fazer crer que eram, e, da mesma forma, o Rio Grande do Sul estava mais longe ainda de ser o "reino da igualdade", sem preconceitos, que até hoje muitos buscam fazer crer que é. 